\title{
(3) Isolation of Nuclei from Adult Human Brain Tissue for 10x Genomics Platform V.1
}

LeinU01 BRAIN grant ${ }^{1}$

${ }^{1}$ Allen Institute

BICCN Allen Institute for Brain Science

\section{VERSION 1}

MAR 13, 2019

\section{open ठaccess}

\section{DOI:}

dx.doi.org/10.17504/protocol s.io.y6rfzd6

Protocol Citation: LeinU01 BRAIN grant 2019. Isolation of Nuclei from Adult Human Brain Tissue for $10 x$ Genomics Platform. protocols.io https://dx.doi.org/10.17504/p rotocols.io.y6rfzd6

License: This is an open access protocol distributed under the terms of the Creative Commons Attribution License, which permits unrestricted use, distribution, and reproduction in any medium, provided the original author and source are credited

Protocol status: Working We use this protocol and it's working

Created: Mar 13, 2019

Last Modified: Mar 13, 2019

PROTOCOL integer ID: 21425

\section{ABSTRACT}

Isolation of nuclei from frozen adult human brain tissue or thawed and microdissected brain tissue sections for RNA-seq analysis.

\section{ATTACHMENTS \\ PF0308_Isolation_of_Nucl \\ ei_from_Adult_Human_Bra \\ in_Tissue_for_10x....docx}

